\title{
Same-Hill Intercropping of Different Plant Species with Faba Bean for Control of Orobanche Crenata
}

\author{
Mahmoud M. Zeid ${ }^{1 *}$ and Doaa A. Komeil ${ }^{2}$
}

\begin{abstract}
Allelopathic effects of some faba bean companion crops have been shown to reduce Orobanche crenata Forsk. seed germination especially in vitro. Field experiments were conducted in two locations to evaluate the effect of different companion crops grown in the same-hill with seeds of the resistant faba bean cultivars Misr 3 and Giza 843 on the number of emerged crenate broomrape spikes. Another field experiment was established to compare the effect of fenugreek intercropped on the opposite-side of the faba bean ridge method to same-hill intercropping method on the number of broomrape spikes emerged and faba bean performance. A bioassay experiment was also employed to study the effect of presence of fenugreek, fennel and radish on inhibition of O.crenata seed germination in presence of the two faba bean cultivars in vitro. The bioassay results indicated that presence of fenugreek as a companion crop inhibits O.crenata seed germination on both cultivars by almost 30\%; however, the values were insignificantly different from the sole-crop. Radish on the other hand, significantly inhibited germination $(\mathbf{7 3 \%})$ in presence of Misr 3 only, while fennel showed no effect on parasite seed germination. Field experiments indicated less number of emerged spikes with opposite-side of the ridge when intercropping fenugreek compared to same-hill intercropping. Results also stressed the role of the faba bean genotype in the host-parasite-companion crop complex. The effect of the companion crop on the number of parasite emerged spikes and yield improvement varied according to the location; however, under farmer's field conditions of a large parasite seed bank, the effect of companion crops was not observed. Companion crops may show allelopathic effects on O.crenata seed germination in vitro, however, these observations need to be verified on farmers' fields before it could be proposed as a feasible control method for O.crenata.
\end{abstract}

KEY WORDS: Allelopathy; Coriander; Fennel; Rocket salad; Parsley; Garlic; Radish

\section{INTRODUCTION}

Faba bean (Vicia faba L.) is an important pulse crop grown for human consumption as a good protein source in the Mediterranean region, Ethiopia and parts of China, while in Europe it is considered a good animal feed and in Australia it is an important stock feed. Reports on yield losses in faba bean due to the infestation with the parasitic weed Orobanche crenata
Forsk. (crenate broomrape), are common in the Mediterranean region, and parts of China. In Egypt, although no official data is available, the area infested with the parasite has expanded greatly and the seed bank has become so enriched that farmers cannot control the parasite using traditional methods of hoeing, late sowing of tolerant cultivars if available. Because damage to faba bean from broomrape occurs before the parasite emerges, farmers cannot risk growing faba bean or other winter legumes anymore. Under heavy soil infestation, glyphosate spraying does not seem to be effective (Zeid and Hemeid, 2019). In addition the rising costs of application and the major health issues recently linked to the herbicide (Zhang et al., 2019), glyphosate should be completely avoided.

Different studies have elaborated the importance of including trap or catch crops in the crop rotation to reduce the parasite seed bank, as seeds of the parasite will remain dormant until exudates of the suitable host become available. A false host "trap crop", that stimulates germination without itself being parasitized (Parker, 1991), or catch crop that stimulates seed germination at a high frequency and gets infested but is destroyed before parasite seed spreading along with the host, are both part of a long term solution to reduce the parasite seed bank (Sauerborn, 1991). Abbes et al. (2008) recognized flax, bread wheat, sunflower, oats, durum wheat and fenugreek as trap crops after observing O.crenata seed germination on their roots in vitro, but no tubercle formation was observed on roots of any plant after 67 days from inoculation. Employing both trap and catch crops, however, indicate that growing faba bean will cease until the parasite seed bank is largely depleted. To tackle this problem, companion crops have been suggested as a method for combating O.crenata infestation while faba bean is growing on the field. Some local Egyptian farmers assume that intercropping faba bean with fenugreek, coriander, garlic and fennel is a good practice for reducing the parasite infestation and guaranteeing excellent yield. These assumptions have been scientifically investigated, where Al-Menoufi (1991), reported a reduction in O.crenata infestation when faba bean was intercropped with fenugreek. Also, Al-Menoufi et al. (1996) indicated

\footnotetext{
DOI: 10.21608/ASEJAIQJSAE.2019.31149

${ }^{1}$ Department of Crop Science, Faculty of Agriculture, Alexandria University, Alexandria, Egypt.

${ }^{2}$ Department of Plant Pathology, Faculty of Agriculture, Alexandria University, Alexandria, Egypt.

* Corresponding author's email: mahmoud.zeid@alexu.edu.eg

Received March 25, 2019, Accepted April 25, 2019
} 
the possibility of intercropping lupin, coriander and Brassica rapa with faba bean or tomato to reduce Orobanche infestation. Bakheit et al. (2002), found a similar trend when fenugreek, lupin and Egyptian clover, were intercropped with the resistant faba bean cultivar Giza 429, causing a reduction of O.crenata spikes that amounted to $58 \%, 56 \%$, and $68 \%$ compared to the control, respectively. Abu-Shall and Ragheb (2014), reported a reduction in O.crenata emerged spikes amounting to $79 \%$ when the cultivar Aquadulce was intercropped with radish, $63 \%$ with celery and berseem clover, $59 \%$ with flax, $52 \%$ with fenugreek and $42 \%$ with garlic. Among the cereal crops, oats appeared to reduce O.crenata infestation in faba bean according to Fernández-Aparicio et al. (2007). Fenugreek was further investigated by Fernández-Aparicio et al. (2008a), who observed $30-41 \%$ reduction in emerged number of spikes when fenugreek was intercropped with Giza blanka in Egypt. They also observed that when the cultivar Brocal was sown in pot experiments (1 Brocal seed and 1 fenugreek seed/pot), the reduction in attached infestations, 3 months from sowing, was estimated to be $49 \%$. However, in larger pots (4 Brocal seed and 16 fenugreek seeds/pot) the reduction in number of attachments was estimated to be $18.3-19.7 \%$ only, depending on the growth chamber's temperature, two months after sowing. Their mini-rhizotron experiments showed that fenugreek appears to stimulate $5 \%$ of O.crenata seeds but does not get infested. Also using the synthetic stimulant GR24 in presence of fenugreek, reduction in O.crenata infestation was estimated to be $16 \%$ at $20^{\circ} \mathrm{C}$ and only $7 \%$ at $28^{\circ} \mathrm{C}$. They concluded that fenugreek roots inhibit O.crenata seed germination only in the vicinity of the host roots, but not affecting the chance of establishment of germinated seeds on host roots. Evidente et al. (2007), demonstrated through bioassays that the inhibition of O.crenata seeds germination when fenugreek was intercropped with pea plants is due to allelopathy and isolated the main inhibiting metabolite that was named trigoxazonane that was chemically characterized as a new monosubstituted trioxazonane.

Taking into account the previously mentioned studies, it appears that companion crops represent a powerful method for combating the parasite while still growing the main crop itself. It is considered a cheap method and cost effective, as farmers will profit from growing two crops, in addition to being environmental friendly, as no herbicides would be employed. The two Egyptian cultivars Giza 843 and Misr 3, showing good levels of resistance to the parasite along with a suitable companion crop, once identified, should provide an excellent base for an integrated broomrape management set that could bring back faba bean to the Egyptian crop rotation.

Thus the objective of this study was to investigate the possibility of controlling Orobanche crenata emergence and yield losses, in two different resistant faba bean cultivars by same-hill intercropping with various companion crops, to levels at which farmers can afford to grow faba bean in broomrape infested soils.

\section{MATERIALS AND METHODS}

\section{1- Field studies}

Seeds of each of the O.crenata resistant faba bean cultivars Giza 843 and Misr 3 were sown in hills on ridges, along with each of the tested companion crops (same-hill intercropping) to study the effect of the companion crop on reduction of O.crenata field infestation. Experiments of the first season (2014/2015) were performed at the Abbis experimental station of the Faculty of Agriculture, Alexandria University in Alexandria, Egypt, on a sandy loam soil plot naturally infested with seeds of the parasite. However, in the second season (2015/2016), experiments were conducted on a farmer's field in Kafr El-Dawar, ElBeheira governorate, characterized by sandy clay loam soil known to be homogenously infested with possibly an aggressive population of O.crenata. Experiments in both seasons were laid out in a randomized complete block design with three replicates. Each experimental unit was made up of 4 ridges $60 \mathrm{~cm}$ wide and 3 meters in length, sown with either faba bean cultivar in hills 25 $\mathrm{cm}$ apart ( 2 seeds/hill). Five to six seeds of each of the companion crops were sown along with the faba bean seeds in the same hill and were later thinned to two seedlings/hill. Check experimental units were also included, where 2 seeds of faba bean were sown/hill with no companion crop added. Sowing was performed on the $1^{\text {st }}$ of November and harvesting was on the 23 of April in both seasons. Phosphorus fertilization was incorporated in the soil during field preparation in the form of calcium super phosphate $\left(15.5 \% \quad \mathrm{P}_{2} \mathrm{O}_{5}\right)$ at the rate of $48 \mathrm{~kg} / \mathrm{ha}$ and no other ground fertilizers were employed, so as not to interfere with the experiment results. A foliar application of $3.1 \% \mathrm{~N}, 1 \% \mathrm{P}_{2} \mathrm{O}_{5}, 2 \%$ $\mathrm{K}_{2} \mathrm{O}, 200$ ppm Mg, 100 ppm Zn, 30 ppm Cu, 0.01\% B and $6 \%$ free amino acids was sprayed after 30 and 45 days from sowing. The companion crops studied were fenugreek (Trigonella foenum-graecum L.), rocket salad (Eruca sativa), fennel (Foenicum vulgare Mill), radish (Raphanus sativus L.), coriander (Coriandrum sativum L.), and parsley (Petroselinum crispum) in the first season, while garlic (Allium sativum L.) replaced parsley in the second season, because parsley failed to germinated. A second experiment was conducted at Kafr El-Dawar location in 2015/2016, using the same 
methods mentioned above, where we compared the effect of opposite-side of the ridge intercropping of fenugreek and same-hill intercropping method on the number of emerged O.crenata spikes/plant and faba bean pod yield. At harvest, data on faba bean plant height $(\mathrm{cm})$, number of tillers/plant, faba bean vegetative biomass $(\mathrm{g})$ and pod yield $(\mathrm{g})$ were recorded from a 3 meter length of the middle two guarded ridges after drying. Also the number of emerged O.crenata spikes was recorded after uprooting the host plants and data was averaged and adjusted to values per single plant basis.

\section{2- In vitro study}

A bioassay for screening O.crenata seed germination, according to Kroschel (2001), was conducted in presence of each of fenugreek, fennel or radish seedlings for both faba bean cultivars and for the two cultivars as sole-crops. Seeds of O.crenata collected from Kafr El-Dawar location, were sprinkled evenly on Whatman filter paper, preconditioned at $24^{\circ} \mathrm{C}$ for 7 days and a germinated seedling of faba bean along with a germinated seedling from the studied companion crops were placed in each prepared Petri dish in three replicates for observation. Thirty days after incubation at $25 / 15^{\circ} \mathrm{C}$ (day/night), O.crenata germinated seeds on roots of the faba bean plants were observed and counted under a stereoscopic microscope.

Statistical analysis was performed using SAS 9.3 software (SAS 2007) for each year separately and square root transformation was applied to discrete traits before analysis. Significance was declared at $\mathrm{P}<0.05$, and the least significant difference (L.S.D) was used for comparison of means.

\section{RESULTS}

\section{1- Field studies}

Analysis of variance for data from the two fields where the study was undertaken showed lack of uniformity among their error of variance for most of the studied traits and consequently results were not combined and were analyzed for each location/year separately as proposed by Winer (1971).

Abbis location

In this location, significant differences were observed for the interaction between the companion crops (CC) and the faba bean cultivars, for all traits except the faba bean vegetative biomass/plant and pod yield/plant (Table 1). Also significant differences were observed for the two treatments on the vegetative biomass/plant and for the CC only on the pod yield/plant. The cultivar Misr 3 significantly surpassed the cultivar Giza 843 in the vegetative biomass/plant by $33.3 \%$ and by $20.4 \%$ regarding pod yield/plant, although the latter was insignificantly different (Table 2). The highest faba bean vegetative biomass was recorded for the sole cultivar and was insignificantly different from the presence of fenugreek, coriander, and fennel as CC, while the least values for that trait were recorded for radish and rocket salad (Table2). Faba bean intercropped with coriander and fennel produced the highest (87.8 and 66.2g, respectively) pod yield/plant and the least values were recorded for radish and rocket salad. Regarding the interaction between the cultivars and the CC, the tallest faba bean plants were observed when Misr3 was intercropped with radish or coriander or Giza 843 intercropped with fenugreek or rocket salad, while the shortest plants were those intercropped with parsley from either cultivar (data not shown). The highest tiller number was observed with the sole faba bean plants of either cultivar or with Giza 843 with fenugreek as a CC and the least number of tillers were recorded for either cultivar when intercropped wit rocket salad (data not shown). The largest number of parasite spikes was observed for the cultivar Misr 3 when intercropped with rocket salad (2.3 spikes/plant), however, this number was insignificantly different from the sole Misr 3, or Giza 843 when intercropped with either coriander, fennel, fenugreek or parsley (Fig. 1). The least number of spikes was observed with Misr 3 when intercropped with fenugreek (zero spikes/plant) and that was insignificantly different from Misr 3 intercropped with coriander, fennel and parsley and Giza 843 intercropped with rocket salad (Fig. 1).

\section{Kafr El-Dawar location}

Contrary to what was observed in the first location, the effect of the interaction between the $\mathrm{CC}$ and the faba bean cultivars was only significant for the pod yield/plant while the effect was insignificant for all other traits (Table 1). There were insignificant effects for the $\mathrm{CC}$ on any of the studied traits; and for the cultivars, significant effects were observed for faba bean plant height and vegetative biomass only while the other traits were insignificantly affected by the cultivars (Table 1). The cultivar Misr 3 was significantly taller $(113.4 \mathrm{~cm})$ and produced more vegetative biomass $(51.7 \mathrm{~g} / \mathrm{plant})$ than the cultivar Giza $843(97.9 \mathrm{~cm}, 31.1 \mathrm{~g} / \mathrm{plant})$ as shown in Table (2). The highest pod yield was observed for the cultivar Misr 3 when intercropped with rocket salad, however, that was not significantly different from intercropping with sole Misr 3, fenugreek, fennel and sole Giza 843 or when Giza 843 was intercropped with either fenugreek or radish (Fig. 2).

Same-hill intercropping versus opposite-side of the ridge intercropping.

Differences between the two intercropping methods were statistically insignificant for all studied traits 
except the main effects of the variety, showing the cultivar Misr 3 to be taller than Giza 843. However, a trend was observed as same-hill intercropping showed higher number of emerged spikes than either the control $(12.2 \%)$ or the opposite-side of the ridge intercropping method (22\%), (Fig. 3). Similarly, the opposite-side of the ridge intercropping method yielded $18.9 \%$ more pod yield than the same-hill intercropping method and $26.2 \%$ more pod yield than the faba bean sole-crop, although these differences were insignificant (Fig. 3).

2- In vitro study
Orthagonal comparisons among all possible differences between the studied treatments of the bioassay (Table 3) indicated that, none of the CC tested had a significant effect on O.crenata seed germination in presence of Giza 843 compared to the sole faba bean plants. On the other hand, radish as a CC showed significant effects, inhibiting O.crenata germination on Misr 3 by $73 \%$ compared to the sole-Misr 3 plants. Similarly, presence of radish with Misr 3 plants germinated significantly lower number of O.crenata seeds compared to Misr 3/fennel (75\%), sole-Giza 843 (71.7\%) and Giza 843/radish (70.58\%).

Table 1.Analysis of variance for faba bean performance, pod yield and broomrape emerged spikes during 2015/2016 and 2016/2107 growing seasons at two different locations

\begin{tabular}{|c|c|c|c|c|c|c|c|c|c|c|c|}
\hline \multirow[t]{2}{*}{ S.O.V } & \multirow[t]{2}{*}{ d.f. } & \multicolumn{2}{|c|}{ Plant height } & \multicolumn{2}{|c|}{$\begin{array}{l}\text { Number of } \\
\text { tillers/plant }\end{array}$} & \multicolumn{2}{|c|}{$\begin{array}{c}\text { Faba bean } \\
\text { vegetative } \\
\text { biomass/plant }\end{array}$} & \multicolumn{2}{|c|}{ Pod yield/plant } & \multicolumn{2}{|c|}{$\begin{array}{l}\text { Number of } \\
\text { spikes/plant }\end{array}$} \\
\hline & & L1 & L2 & L1 & L2 & L1 & L2 & L1 & L2 & L1 & L2 \\
\hline Replicate & 2 & 120.62 & 230.86 & 0.023 & 0.056 & 280 & 2198 & 670 & 73 & 0.01 & 0.043 \\
\hline Cultivar (A) & 1 & $1.64^{\mathrm{ns}}$ & $2519.3^{* *}$ & $0.09^{*}$ & $0.002^{\mathrm{ns}}$ & $1760^{*}$ & $4476^{* *}$ & $1020^{\mathrm{ns}}$ & $88^{\mathrm{ns}}$ & $0.57^{*}$ & $0.016^{\mathrm{ns}}$ \\
\hline $\begin{array}{l}\text { Companion } \\
\text { crop (B) }\end{array}$ & 6 & $292.27^{* *}$ & $55.99^{\mathrm{ns}}$ & $0.96^{* *}$ & $0.017^{\mathrm{ns}}$ & $1140^{*}$ & $501^{\mathrm{ns}}$ & $3100^{* *}$ & $52^{\mathrm{ns}}$ & $0.076^{\mathrm{ns}}$ & $0.12^{\mathrm{ns}}$ \\
\hline$A \times B$ & 6 & $119.05^{\text {** }}$ & $57.08^{\mathrm{ns}}$ & $0.19^{* *}$ & $0.003^{\mathrm{ns}}$ & $310^{\mathrm{ns}}$ & $701^{\mathrm{ns}}$ & $200^{\mathrm{ns}}$ & $193^{*}$ & $0.59^{* *}$ & $0.152^{\mathrm{ns}}$ \\
\hline Error & 26 & 27.48 & 63.8 & 0.02 & 0.009 & 130 & 320 & 380 & 70 & 0.13 & 0.105 \\
\hline
\end{tabular}

L1: 2015/2016 growing season at Abbis location.

L2: 2016/2107 growing season at Kafr El-Dawar location.

ns: not significant at 0.05 level of probability.

${ }^{*}, * *$ : significant at 0.05 and 0.01 levels of probability, respectively.

Table 2. Means for plant height, number of tillers/plant, faba bean vegetative biomass/plant, pod yield/plant and number of spikes/plant as affected by the cultivar and the companion crop for the 2015/2016 and 2016/2017 growing season the two different locations

\begin{tabular}{|c|c|c|c|c|c|c|c|c|c|c|}
\hline \multirow[t]{2}{*}{ Treatment } & \multicolumn{2}{|c|}{$\begin{array}{l}\text { Plant height } \\
(\mathrm{cm})\end{array}$} & \multicolumn{2}{|c|}{$\begin{array}{l}\text { Number of } \\
\text { tillers/plant }\end{array}$} & \multicolumn{2}{|c|}{$\begin{array}{c}\text { Faba bean } \\
\text { vegetative } \\
\text { biomass/plant }(\mathrm{g})\end{array}$} & \multicolumn{2}{|c|}{$\begin{array}{l}\text { Pod yield/plant } \\
\text { (g) }\end{array}$} & \multicolumn{2}{|c|}{$\begin{array}{l}\text { Number of } \\
\text { spikes/plant }\end{array}$} \\
\hline & L1 & L2 & L1 & L2 & L1 & L2 & L1 & L2 & L1 & L2 \\
\hline \multicolumn{11}{|c|}{ Cultivar } \\
\hline Giza 843 & $80.21 \mathrm{a}$ & $\begin{array}{l}97.88 b \\
113.37\end{array}$ & $3.91 \mathrm{a}$ & $4.36 \mathrm{a}$ & $35.5 b$ & $31.1 \mathrm{~b}$ & $49.4 \mathrm{a}$ & $10.9 \mathrm{a}$ & $0.71 \mathrm{a}$ & $9.42 \mathrm{a}$ \\
\hline Misr 3 & $80.60 \mathrm{a}$ & $\mathrm{a}$ & $3.55 \mathrm{~b}$ & $4.30 \mathrm{a}$ & $48.4 \mathrm{a}$ & $51.7 \mathrm{a}$ & $59.2 \mathrm{a}$ & $13.8 \mathrm{a}$ & $0.61 \mathrm{~b}$ & $9.21 \mathrm{a}$ \\
\hline \multicolumn{11}{|c|}{ Companion crop } \\
\hline Sole-faba bean & $79.68 b c$ & $101.82 \mathrm{a}$ & $5.62 \mathrm{a}$ & $4.52 \mathrm{a}$ & $52.0 \mathrm{a}$ & $36.7 \mathrm{ab}$ & $57.5 b$ & $15.9 \mathrm{a}$ & $0.60 \mathrm{a}$ & $9.89 a$ \\
\hline Coriander & $84.00 \mathrm{abc}$ & $106.60 \mathrm{a}$ & $3.60 \mathrm{c}$ & $4.18 \mathrm{ab}$ & $53.9 \mathrm{a}$ & $32.3 b$ & $87.8 \mathrm{a}$ & $9.2 \mathrm{a}$ & $0.70 \mathrm{a}$ & $10.43 a$ \\
\hline Fennel & $78.17 \mathrm{c}$ & $109.31 \mathrm{a}$ & $4.35 b$ & $3.99 \mathrm{~b}$ & $45.7 \mathrm{ab}$ & $42.9 \mathrm{ab}$ & $66.2 \mathrm{ab}$ & $9.4 \mathrm{a}$ & $0.42 \mathrm{a}$ & $8.99 a$ \\
\hline Fenugreek & $85.33 \mathrm{ab}$ & $105.97 \mathrm{a}$ & $4.81 \mathrm{~b}$ & $4.47 \mathrm{a}$ & $55.9 \mathrm{a}$ & $51.6 \mathrm{ab}$ & $57.4 \mathrm{~b}$ & $15.2 \mathrm{a}$ & $0.48 \mathrm{a}$ & $8.10 \mathrm{a}$ \\
\hline Parsley/Garlic* & $66.10 \mathrm{~d}$ & $102.57 \mathrm{a}$ & $3.59 \mathrm{c}$ & $4.21 \mathrm{ab}$ & $36.3 b c$ & $40.0 \mathrm{ab}$ & $60.2 b$ & $10.7 \mathrm{a}$ & $1.19 \mathrm{a}$ & $8.70 \mathrm{a}$ \\
\hline Radish & $86.62 \mathrm{a}$ & $103.75 a$ & $2.75 \mathrm{~d}$ & $4.36 \mathrm{ab}$ & $19.1 \mathrm{~d}$ & $31.0 \mathrm{~b}$ & $18.1 \mathrm{c}$ & $11.1 \mathrm{a}$ & $0.63 \mathrm{a}$ & $10.12 \mathrm{a}$ \\
\hline Rocket salad & $82.92 \mathrm{abc}$ & $109.38 \mathrm{a}$ & $1.38 \mathrm{e}$ & $4.58 \mathrm{a}$ & $30.6 \mathrm{~cd}$ & $54.8 \mathrm{a}$ & $32.6 \mathrm{c}$ & $15.2 \mathrm{a}$ & $0.59 \mathrm{a}$ & $8.95 \mathrm{a}$ \\
\hline
\end{tabular}

L1: 2015/2016 growing season at Abbis location.

L2: 2016/2107 growing season at Kafr El-Dawar location.

* Parsley was the companion crop in L1 and garlic replaced it in L2.

Means followed by the same letter (s) within the same column are insignificantly different at 0.05 level of probability. 


\section{Pod yield (g/plant) $\quad$ No. spikes/plant}

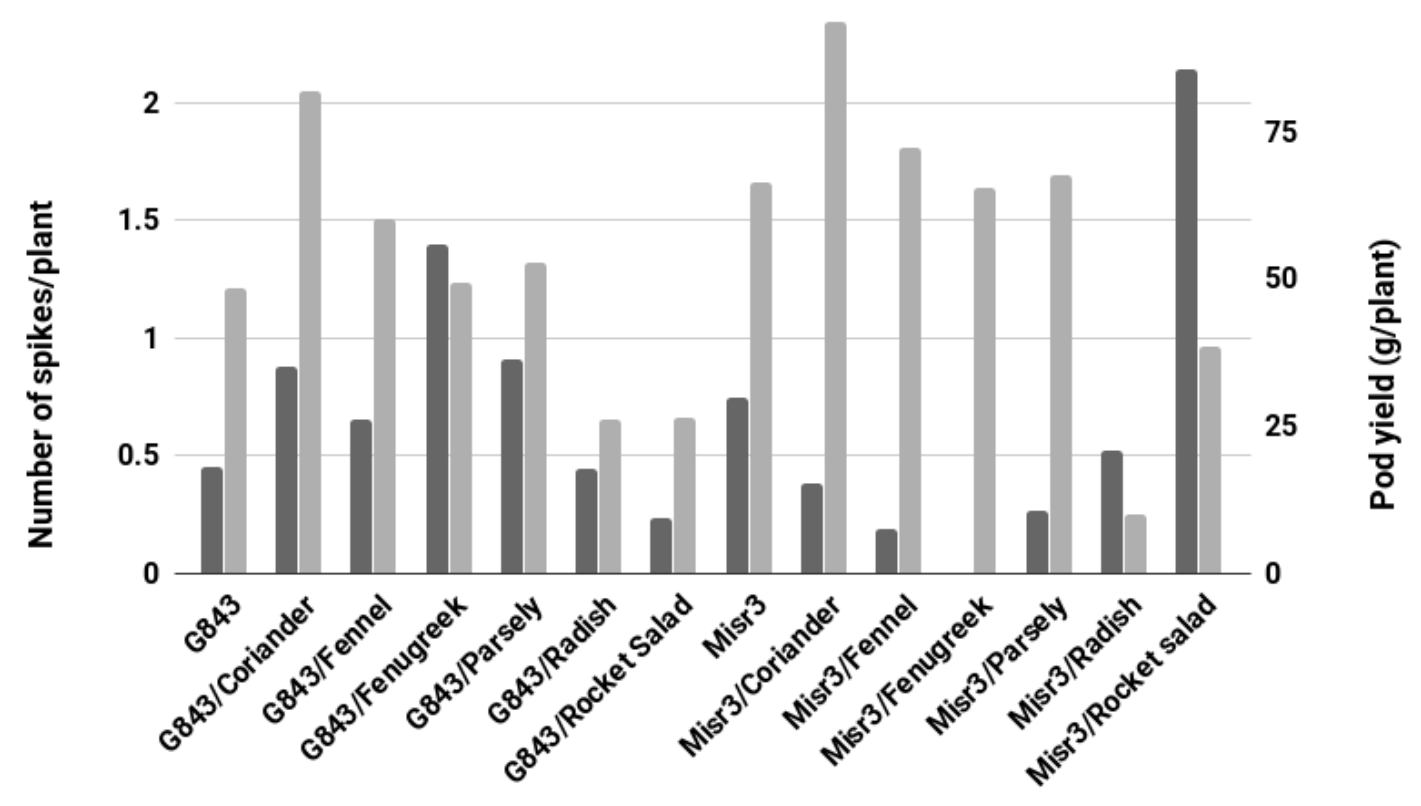

Fig. 1. Pod yield of the faba bean cultivars Misr3 and Giza843 (G843) grown in presence of six different companion crops or as sole plants and the number of emerged broomrape spikes observed for each case, when grown in Abbis location in the 2015/2016 growing season. L.S.D for number of spikes/plant $=\mathbf{0 . 6 2}$.

Pod yield (g/plant) $\quad$ No. spikes/plant

12 30

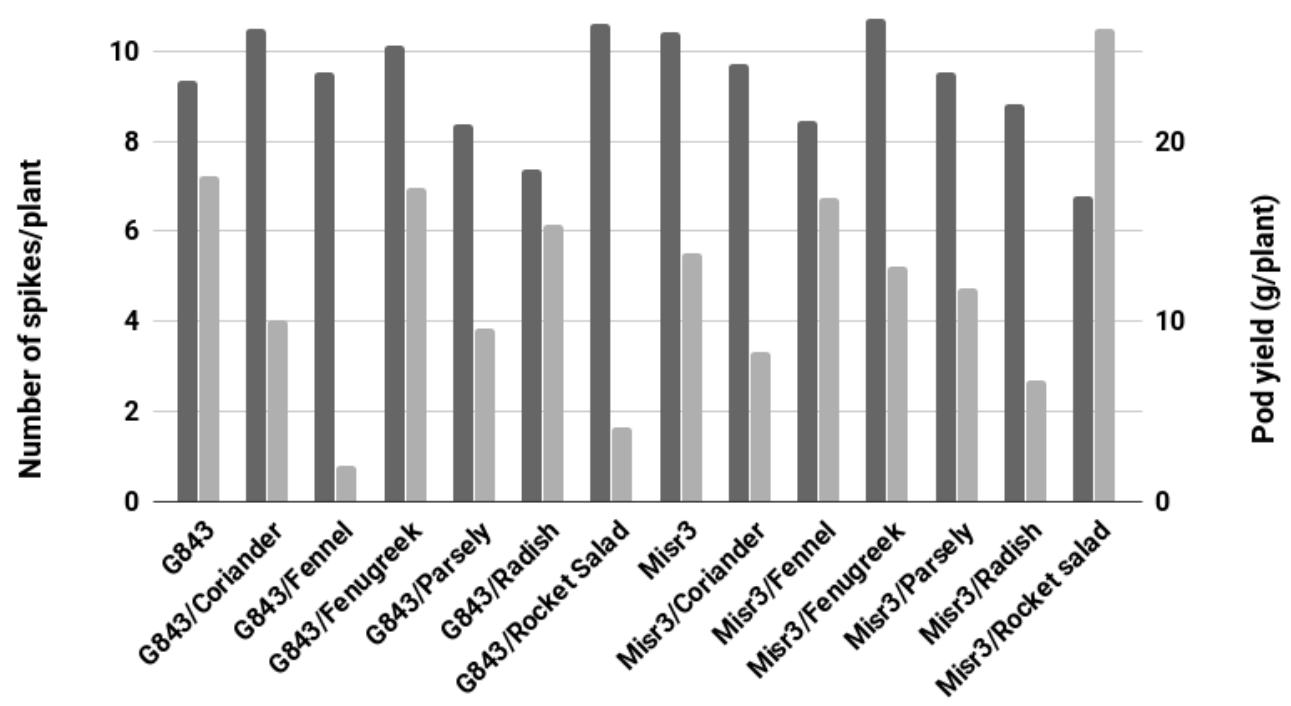

Fig. 2. Pod yield of the faba bean cultivars Misr3 and Giza843 (G843) grown in presence of six different companion crops or as sole plants and the number of emerged broomrape spikes observed for each case, when grown in Kafr El-Dawar location in the 2016/2017 growing season. L.S.D for pod weight (g/plant) = 14.48. 


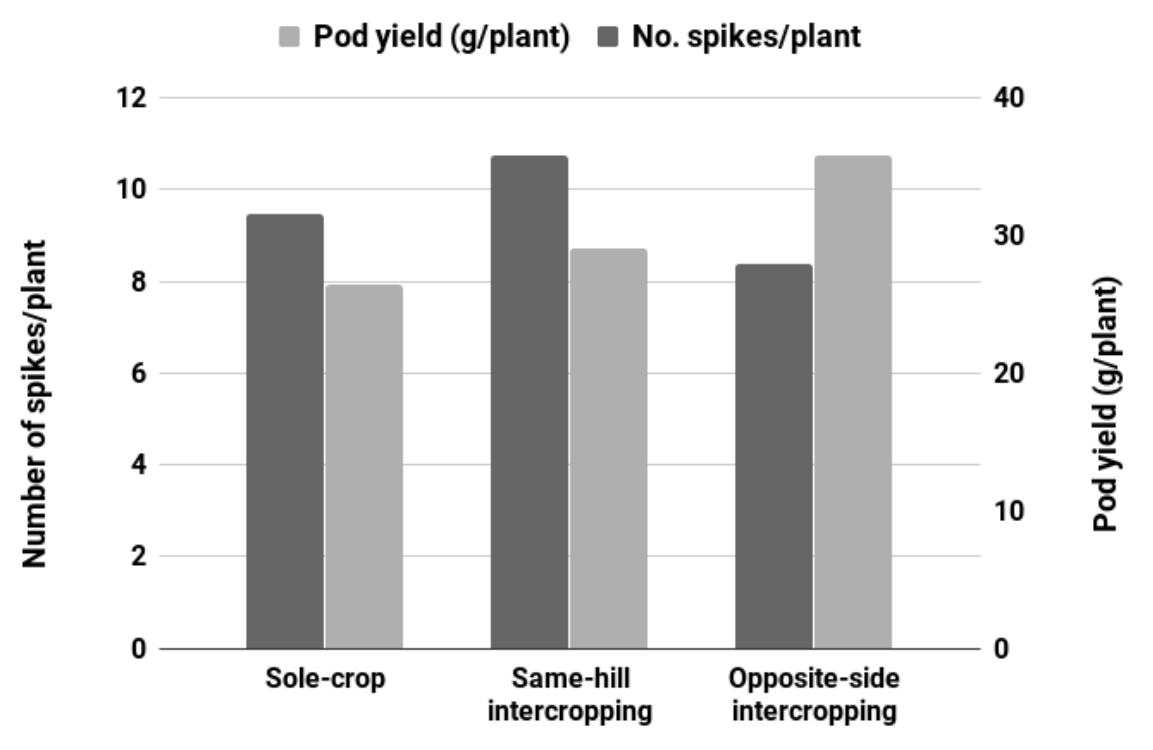

Fig. 3. Pod yield of faba bean cultivars and number of emerged broomrape spikes grown as a sole-crop and in presence of fenugreek as same-hill versus opposite-side of the ridge intercropping, grown in Kafr El-Dawar location in the 2016/2017 growing season.

Table 3. Differences between the numbers of $O$.crenata seeds germinated in presence of Misr3 and Giza 843 as sole seedlings and in presence of fenugreek, fennel and radish seedlings as companion crops

\begin{tabular}{|c|c|c|c|c|c|c|c|}
\hline Treatments & $\begin{array}{l}\text { Misr 3/ } \\
\text { fenugreek }\end{array}$ & $\begin{array}{l}\text { Misr 3/ } \\
\text { fennel }\end{array}$ & $\begin{array}{l}\text { Misr3/ } \\
\text { radish }\end{array}$ & $\begin{array}{l}\text { Giza } 843 / \\
\text { sole }\end{array}$ & $\begin{array}{l}\text { Giza } 843 / \\
\text { fenugreek }\end{array}$ & $\begin{array}{l}\text { Giza 843/ } \\
\text { fennel }\end{array}$ & $\begin{array}{l}\text { Giza } 843 / \\
\text { radish }\end{array}$ \\
\hline $\begin{array}{l}\text { Misr 3/ } \\
\text { sole }\end{array}$ & 18.17 & -3.67 & $46.0^{*}$ & 3.67 & 23.0 & 2.17 & 5.42 \\
\hline $\begin{array}{l}\text { Misr 3/ } \\
\text { fenugreek }\end{array}$ & - & -21.83 & 27.83 & -14.50 & 4.83 & -16.0 & -12.75 \\
\hline $\begin{array}{l}\text { Misr 3/ } \\
\text { fennel }\end{array}$ & & - & $49.67 *$ & 7.33 & 26.67 & 5.83 & 9.08 \\
\hline $\begin{array}{l}\text { Misr 3/ } \\
\text { radish }\end{array}$ & & & - & $-42.33 *$ & -23.0 & -43.83 & $-40.58^{*}$ \\
\hline $\begin{array}{l}\text { Giza } 843 / \\
\text { sole }\end{array}$ & & & & - & 19.33 & -1.50 & 1.75 \\
\hline $\begin{array}{l}\text { Giza 843/ } \\
\text { fenugreek }\end{array}$ & & & & & - & -20.83 & -17.58 \\
\hline $\begin{array}{l}\text { Giza } 843 \\
\text { fennel }\end{array}$ & & & & & & - & 3.25 \\
\hline
\end{tabular}

Although insignificant, fenugreek had an inhibitory effect on O.crenata seed germination that amounted to $29 \%$ compared to sole-Misr3 and 33\% compared to sole-Giza843. Petri dishes with sole fenugreek, fennel and radish germinated 4,10 and 2 O.crenata seeds, respectively, and germinated seeds were distantly located from any of the screened plant roots.

\section{DISCUSSION}

The presented results clearly demonstrated that although the cultivar Giza 843 tended to produce more tillers than Misr 3, the latter was more vigorous with taller plants, accumulating more vegetative biomass, producing more pod yield and harboring less number of spikes under O.crenata infestation, in both locations under study. These results are in agreement with Zeid 
and Hemeid (2019), who observed that the recently developed Misr 3 outperformed the older Giza 843 under O.crenata infestation both in pod yield and in reducing the number of emerged spikes/plant.

Fenugreek has long been recognized as a companion crop with positive effects on O.crenata reduction in faba bean when grown either on the opposite-side of the ridge (Bakheit et al., 2002) or broadcasted in the faba bean field in varying ratios (Fernández-Aparicio et al., 2008a). But in mini-rhizotron studies that indicated inhibitory effects of fenugreek on O.crenata (Evidente et al., 2007 and Fernández-Aparicio et al., 2008a), fenugreek roots were growing in the same premises along with roots of the host plant. Whitney and Carsten (1981) pointed out the importance of the concentration of the root exudates in stimulating or inhibiting the germination of O.crenata and that the inhibitory effects of high concentration of the exudates may control the radicle growth pattern in a way to ensure successful contact with the host roots. Taking the above mentioned research into consideration, the effect of same-hill intercropping of fenugreek was compared with the opposite-side of the ridge intercropping method, regarding number of emerged O.crenata spikes/plant and pod yield/plant. Results presented in Figure (3) indicated that neither the same-hill nor opposite-side of the ridge intercropping methods differed significantly from the control (faba bean sole-crop). However, a trend was observed showing superiority of the opposite-side of the ridge intercropping method to the same-hill intercropping method in the amount of yield produced and in the lower number of emerged spikes observed. These results suggest that the same-hill intercropping method, where the roots of the fenugreek are in close premises to the faba bean roots as employed by in vitro methods, was not the most suitable technique for field experiments and that a distance should be maintained between roots of faba bean and those of fenugreek. A definite conclusion regarding these effects cannot be drawn as yet.

In Abbis location, no O.crenata spikes were observed when fenugreek was same-hill intercropped with Misr 3 compared to 0.75 spikes/plant observed in the Misr 3 sole-crop suggesting complete parasite inhibition in presence of fenugreek. These results observed for the resistant cultivar Misr 3, are in full agreement with the observation of Fernández-Aparicio et al. (2008a), who suggested an allelopathic effect of fenugreek root exudates affecting germination of O.crenata on the susceptible cultivar Giza Blanca $(60 \%$ reduction in parasite spikes on the field) and on the susceptible cultivar Brocal (49\% reduction in tubercles/host plant in pot experiments). Evidente et al.
(2007), also observed up to 54\% inhibition in O.crenata seed germination due to fenugreek root exudates. However, these results disagree with those reported by Fernández-Aparicio et al. (2008b), who reported a $23.7 \%$ O.crenata seed germination due to fenugreek crude root exudates as compared to $31.1 \%$ due to the positive control, GR24 and consequently considered fenugreek as a suitable trap crop. The contradiction between the results of the chromatographic fractions of the fenugreek root exudates from both studies were explained by Fernández-Aparicio et al. (2011) as that both stimulants and inhibitors are exudates of roots of fenugreek. However, a second plausible explanation came from Qasem and Foy (2001), who proposed that root exudates can act as germination stimulants at low concentrations but different actions might be expected at higher concentrations.

The inhibitory effects of fenugreek on O.crenata observed for Misr 3 in Abbis location were not observed with the cultivar Giza 843, seen harboring significantly higher number of spikes (Fig. 1), thus stressing the significance of the faba bean genotype effect as a key factor in faba bean-O.crenata-companion crop allelopathic effect. Among the tested companion crops, coriander, fennel and parsley intercropped with Misr 3 and also rocket salad intercropped with Giza 843 showed significantly the least number of emerged spikes, however, no effects on pod yield were observed. Results from the bioassay support the effect of the genotype on the faba bean-O.crenata-companion crop complex, where presence of radish with Misr 3, caused a $73.4 \%$ reduction in O.crenata seed germination compared to the control (Misr 3 sole-crop), while the reduction was only $3.9 \%$ for Giza 843 (Table 3). The same trend was observed with radish as a CC with Misr 3 and Giza 843 grown in vitro. This suggests that, variation in parasite seed germination percentage in presence of a CC is not dependent on the allelochemicals produced by the companion crop per se; rather on changing the concentration of the exudates of the faba bean genotype, assuming faba bean genotypes exude the same germination stimulant/s and at the same growth stage. This is probably the first report to signify the importance of the host genotype on the fate of the allelochemicals produced by the companion crop rather than the usually proposed effect of the genotype of the companion crop producing the allelochemical itself as indicated by Khalaf (1994) and Qasem and Foy (2001). The inhibitory effects of radish, observed in this study, on O.crenata seed germination with Misr 3 in vitro, were very promising as compared to fenugreek. Interestingly, field observations from Abu-Shall and Ragheb (2014), reported $79 \%$ reduction in O.crenata emerged spikes when the cultivar Aquadulce was 
intercropped with radish. These observations along with the bioassay results reported here, stress the importance of further studies on radish as a possible useful companion crop using the opposite-side of the ridge method.

In Kafr El-Dawar location, which is a heavily infested farmer's field, representing the exact situation farmers are facing today, the $\mathrm{CC}$ effects and the interaction between the $\mathrm{CC}$ and the cultivar regarding O.crenata emerged spikes were insignificant. Furthermore, the number of emerged spikes was nine fold that observed in Abbis location, suggesting that the effect of companion crops under heavy infestation conditions became irrelevant. These results are in full agreement with Kleifeld et al. (1994) working on Egyptian broomrape, who concluded that positive effects of trap or catch crops would be very limited in heavily infested fields. Their results also pointed out the influence of the environmental conditions and the source of the parasite seeds (represented by the location of this study) on the results observed. The differences in the results from the two studied locations could be due to the possible variation in aggressiveness in O.crenata sources on host performance and/or seed vigor and secondary dormancy. The existence of variation in the aggressiveness of the parasite was observed in the studies of Radwan et al. (1988) and Nawar et al. (1999). Parasite seed vigor is related to the time of first emergence of parasite spikes and to their final number and has been explained by Molinero-Ruiz (2008), while secondary dormancy has been observed by Lopez Granados and Torres (1999) and Murdoch and Ellis (2000). The first location (Abbis) is a research station, where the field is infested with the seeds of the parasite but is not regularly grown with faba bean. The second location (Kafr El-Dawar), however, was a farmer's field and has been grown with faba bean for four consecutive years. It could thus be assumed that the parasite seed bank in the farmer's field was much larger, of higher seed vigor and probably showing low secondary seed dormancy compared to the Abbis location. This may explain why the Egyptian faba bean breeding program has been successful in selecting for resistance to broomrape, as selection is routinely performed under heavily infested soils with freshly harvested parasite seeds constantly being deposited in the faba bean lines selection and evaluation fields (Nassib et al., 1982 and Attia et al., 2013). This also points out how the failure to implement the recommended three-year crop rotation in Egypt, since 1994, has aggravated the O.crenata problem (large seed bank with fresh broomrape seed constantly being deposited each year) in farmers' fields leading to farmers eventually abandoning the crop. Also the reduction of areas grown with cotton in summer and flax in winter could have played a major role in the O.crenata problem escalation, as both were designated as effective trap crops for a number of Orobanche species. According to Fernández-Aparicio et al. (2009), flax exudates induced the germination of Phelipanche aegyptiaca by $78.5 \%$, O.minor by $69.5 \%$, P.ramosa by $48.0 \%$, O.crenata by $42.0 \%$ and O.foetida by $0.7 \%$. We found no research on the effect of Gossypium barbadense on O.crenata, however, Gossypium hirsutum exudates (source of the first isolated germination stimulant; strigol), did germinate O.cumana (Rodriguez-Ojeda, 2001) and P.ramosa (84\%) according to Fernández-Aparicio et al. (2009), but no germination was observed for O.crenata seeds.

The host-parasite-companion crop complex is very challenging, especially when in vitro results are compared to field studies. Despite the fact that many in vitro studies have proposed that fenugreek exudates have allelopathic effects on O.crenata seed germination, this must not indicate the occurrence of allelopathy under natural conditions. The opinion that exudates are subjected to many factors during their release in the field including; environmental conditions (temperature and moisture), parasite seed condition (seed bank size, aggressiveness and secondary dormancy) and the rhizosphere (soil, moisture content, nutritional condition and the root microbiome), that could change their concentration or modify them, has been elaborated by Qasem and Foy (2001). Furthermore, van Woerden et al. (1994), observed that diluted root exudates from Giza 402 stimulated germination of O.crenata more than concentrated exudates. It is also observed that the method of acquiring root exudates in the lab by itself, apart from all the above mentioned factors, may alter the optimum concentration suitable for successful seed germination. An interesting example is noted when comparing the heavy yield and quality losses in parsley fields due to O.crenata infestation in the study of Goldwasser et al. (2003), with the lack of germination of O.crenata seeds using parsley root exudates in vitro as reported by Fernández-Aparicio et al. (2009).

The rate of depletion of the Orobanche sp. seed bank in the soil is assumed to have been over estimated, because previous studies employing seed bags have overseen the effect of soil-borne pathogens on parasite seed mortality as indicated by Mourik et al. (2005). This implies that the O.crenata problem in Egypt will continue to pose a threat to faba bean production for many years to come. It is thus recommended to halt faba bean growing in heavily infested areas and to prevent addition of fresh parasite seeds to such areas by preventing mechanical seed transmition and preventing growth of weed-host plants, like Melilotus spp. and 
Medicago hispida, often seen infested by the parasite in farmers' fields. At the same time a proper crop rotation that includes trap crops especially flax must be implemented aiming to reduce the parasite seed bank and the effect of Gossypium barbadense in the crop rotation should be investigated. In conclusion, the work presented here elaborated the effect of the faba bean cultivar and the location (environment, parasite and rhizosphere) on the host-parasite relationship in presence of the companion crop. It also suggested that the role of the companion crops studied here was confined to disturbing the signal produced by faba bean (the exudates) to stimulate the parasite germination but only under certain conditions. The inconsistency of the effects of the companion crops on O.crenata infestation renders them unsuitable as an efficient method to combat O.crenata under heavy infestation using the same-hill intercropping method.

\section{ACKNOWLEDGEMENT}

This work was partially funded by the project: AGRV-11, Research Enhancement Program, Alexandria University, Alexandria, Egypt.

\section{REFERENCES}

Abbes, Z., M. Kharrat, and W. Chaibi. 2008. Seed germination and tubercle development of Orobanche foetida and Orobanche crenata in presence of different plant species. Tuni. J. Plant Prot. 3(2):101-109.

Abu-Shall, A.M.H. and E.I.M. Ragheb. 2014. Management of Orobanche crenata using trap crops and Phytomyza orobanchia Kalt. in Broad Bean (Vicia faba) Field in Egypt. Egypt. J. Biol. Pest Contr. 24(1):217-223.

Al-Menoufi, O.A. 1991. Crop rotation as a control measure of Orobanche crenata in Vicia faba field. In: Wegmann, K., L.J. Musselman, (eds.). Progress in Orobanche research. Proceedings of the international workshop on Orobanche research, Obermarchtal, 1989. EberhardKarls University, Tübingen, Germany, pp. 241-247.

Al-Menoufi, O.A., M.A. Adam and Nadia A. El-Safwani. 1996. Biological and chemical inhibition of Orobanche seed germination. In: Advances in parasitic plant research. Moreno, M.T., J.I. Cubero, D. Berner, D. Joel, L.J. Musselman, and C. Parker, (eds.). Proceedings of the $6^{\text {th }}$ international parasitic plant symposium, Cordoba, Spain, pp. 417-423.

Attia S.M., M.M. El-Hady, H.A. Saber, M.A. Omer, S.A. Khalil, S.A. Mahmoud, A.A. Ashrei, M.A. Ibrahim, Z.E. Ghareeb, T.S. El-Marsafawy and E.H. El-Harty. 2013. Misr 3, a new Orobanche tolerant faba bean variety. Egypt. J. Plant Breed. 203:1-21.

Bakheit, B.R., A.Y. Allam and A.H. Galal. 2002. Intercropping faba bean with some legume crops for control of Orobanche crenata.Acta Agronomica Hung. 50(1):1-6.
Evidente, A., M. Fernández-Aparicio, A. Andolfi, D. Rubiales, and A. Motta. 2007. Trigoxazonane, a monosubstituted trioxazonane from Trigonella foenumgraecum root exudate, inhibits Orobanche crenata seed germination. Phytochemistry, 68(19):2487-2492.

Fenández-Aparicio, M., J.C. Sillero, and D. Rubiales. 2007. Intercropping with cereals reduces infection by Orobanche crenata in legumes. Crop Prot. 26(8):11661172.

Fernández-Aparicio, M., A.A. Emeran, and D. Rubiales. 2008a. Control of Orobanche crenata in legumes intercropped with fenugreek (Trigonella foenumgraecum). Crop Prot. 27(3-5):653-659.

Fernández-Aparicio, M., A. Andolfi, A. Evidente, A. Pérezde-Luque, and D. Rubiales. 2008b. Fenugreek root exudates show species-specific stimulation of Orobanche seed germination. Weed Res. 48(2):163-168.

Fernández-Aparicio, M., F. Flores, and D. Rubiales. 2009. Recognition of root exudates by seeds of broomrape (Orobanche and Phelipanche) species. Ann. Botany. 103(3):423-431.

Fernández-Aparicio, M., J.H. Westwood, and D. Rubiales. 2011. Agronomic, breeding, and biotechnological approaches to parasitic plant management through manipulation of germination stimulant levels in agricultural soils. Botany. 89(12):813-826.

Goldwasser, Y., H. Eizenberg, S. Golan, and Y. Kleifeld. 2003. Control of Orobanche crenata and Orobanche aegyptiaca in parsley. Crop Prot. 22(2): 295-305.

Khalaf, K.A. 1994. Intercropping fenugreek with faba bean or Egyptian clover: prospects for Orobanche crenata control. In: Pieterse, A.H., J.A.C. Verkleij, S.J. ter Borg, (eds.). Biology and management of Orobanche, proceedings of the third international workshop on Orobanche and related striga research. Royal Tropical Institute, Amsterdam, The Netherlands, pp. 502-504.

Kleifeld, Y., Y. Goldwasser, G. Herzlinger, D.M. Joel, S. Golan, and D. Kahana. 1994. The effects of flax (Linum usitatissimum L.) and other crops as trap and catch crops for control of Egyptian broomrape (Orobanche aegyptiaca Pers.). Weed Res. 34(1):37-44.

Kroschel, J. 2002. A technical manual for parasitic weed research and extension. Springer Science and Business Media, pp. 60-65.

López-Granados, F., and L. García-Torres. 1996. Effects of environmental factors on dormancy and germination of crenate broomrape (Orobanche crenata). Weed Sci. 44:284-289.

Molinero-Ruiz, M.L., B. Perez-Vich, R. Pineda-Martos, and J.M. Melero-Vara. 2008. Indigenous highly virulent accessions of the sunflower root parasitic weed Orobanche cumana. Weed Res. 48(2):169-178.

van Mourik, T.A., T.J. Stomph, and A.J. Murdoch. 2005. Why high seed densities within buried mesh bags may overestimate depletion rates of soil seed banks. J. App. Eco. 42(2):299-305. 
Murdoch, A.J., and R.H. Ellis .2000. Dormancy, viability and longevity. Seeds: the ecology of regeneration in plant communities. 2:183-214.

Nassib A.M., A.A. Ibrahim and S.A. Khalil. 1982. Breeding for resistance to Orobanche. Faba bean improvement. Springer, pp. 199-206.

Nawar A., M.M. Zeid, F.M.F. Zaitoun, M.A. Madkour and Y.S. Koraiem. 1999. Variation among three Orobanche crenata accessions in their virulence in relation to growth and yield characters of the faba bean cultivars Giza 3 and Giza 429. In: Kroschel M. and H.B. Abderabihi, (eds.). Advances in parasitic weed control at on-farm level Vol. II Joint action to control Orobanche in the WANA region Magraf Verlag, Weikersheim, Germany, pp. 215-225.

Parker, C. 1991. Protection of crops against parasitic weeds. Crop Prot. 10:6-22.

Qasem, J.R., and C.L. Foy. 2001. Weed allelopathy, its ecological impacts and future prospects: a review. J. Crop Prod. 4(2):43-119.

Radwan M.S., M.M.F. Abdalla, G. Fischbeck, A.A. Metwally and D.S. Darwish. 1988. Variation in reaction of faba bean lines to different accessions of Orobanche crenata Forsk. Plant Breed. 101(3):208-216.

Rodriguez-Ojeda, M.I., L.C. Alonso and J. FernandezEscobar. 2001. Effect of different crops on the germination of Orobanche cernua Loelf. (O.cumana Wallr.) seeds. In: Fer A., P. Thalouarn, D.M. Joel, L.J. Musselman, C. Parker and J.A.C. Verkleij, (eds.). Proceedings of the $7^{\text {th }}$ international parasitic weed symposium, Nantes, France. p. 124.
SAS. 2007. SAS Institute, Inc. SAS Technical Report SAS/STAT Software; Changes and Enhancements Users Guide. Volume 2, Version 9.1.3, Fourth Edition, Cary, NC: SAS Institute Inc.

Sauerborn, J., 1991. Parasitic flowering plants, ecology and management. Verlag Josef Margraf

Scientific Books, Germany. 127p.

Whitney, P.J., and C. Carsten. 1981. Chemotropic response of broomrape radicles to host root exudates. Ann. Botany, 48(6): 919-921.

Winer, B.J. 1971. Statistical principles in experimental design. $2^{\text {nd }}$ Edition. McGraw-Hill Kogakusha, LTD.

van Woerden, I.C., A. van Ast, F.M.F. Zaitoun, and S.J. ter Borg. 1994. Root exudates of resistant faba bean cultivars are strong stimulants of broomrape germination. In: Pieterse, A.H., J.A.C. Verkleij, S.J. ter Borg, (eds.). Biology and management of Orobanche, proceedings of the $3^{\text {rd }}$ international workshop on Orobanche and related striga research. Royal Tropical Institute, Amsterdam, The Netherlands, pp. 169-172.

Zeid M.M. and Hemeid M.H. 2019. Effect of glyphosate on performance of faba bean varieties under heavy infestation of Orobanche crenata. Alex. Sci. Exch. J. 40(1):169-176.

Zhang, L., I. Rana, E. Taioli, R.M. Shaffer, and L. Sheppard. 2019. Exposure to glyphosate-based herbicides and risk for non-hodgkin lymphoma: A meta-analysis and supporting evidence.Mut. Res./Rev. in Mutat. Res. https://doi.org/10.1016/j.mrrev.2019.02.001. 


\section{الملخص العربي}

\section{أثر تحميل بعض الأنواع النباتيه فى نفس الجوره مع الفول البلاى على مكافحة الهالوك}

$$
\text { محمود محمد زيد - دعاء عبد المحسن كميل }
$$

الهالوك فى حالة الصنف مصر ب بنسبة معنوية جداً (\%Vr) rعـ. أما بذور الثمرفلم يكن لها تأثير على تثنيط إنبات

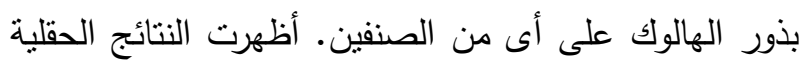

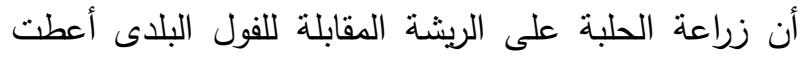

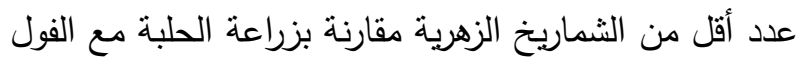

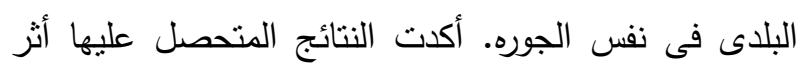
التزكيب الوراثى للفول البلدى على العلاقة المركبة بين كل

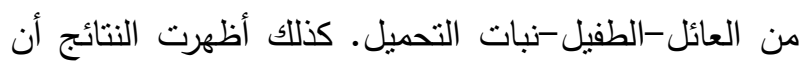

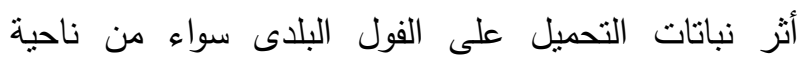

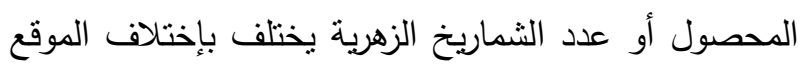
الذى تتم فيه الدراسه، أما تحت الظروف الحقيقية للفلاح المصرى فإن وجود محاصيل التحميل المختلفة فى نفس النس النس

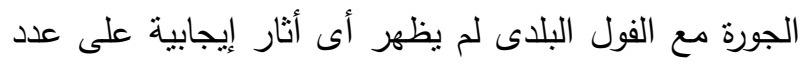
الثماريخ الزهرية أو على المحصول. تخلص الدراسة إلى أنه

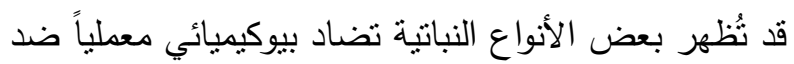

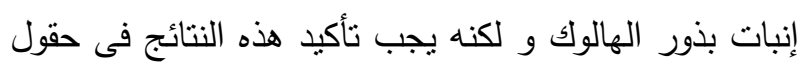
الفلاحين قبل طرحها للتطبيق الفعلى.
أظهرت دراسات سابقة أن التضاد البيوكيميائي لبعض

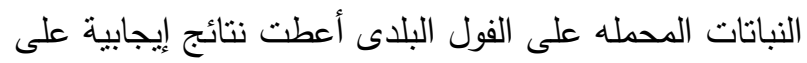
مقاومة الهالوك، خاصة معملياً. لذلك أجريت تجارب حقلية

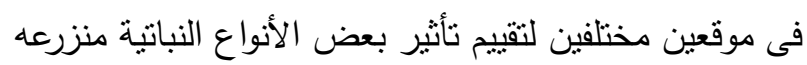
فى نفس الجوره مع صنفى الفول البلدى المقاومين للهالوك جيزه rی و و مصر r على عدد الثماريخ الزهرية للطفيل

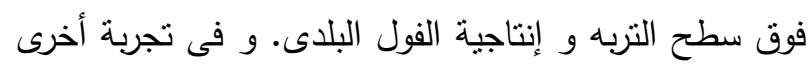
تمت الدقارنه بين تحميل الحلبة فى نفس الجوره أو على القى الريشة المقابلة مع الفول البلدى. كذلك أجريت تجربة معملية بإستخدام أطباق البنرى لدراسة أثثافرازات جذور الحلبة و العابل الثمر و الفجل على إنبات بذور الهالوك فى وجود الفول الفرات

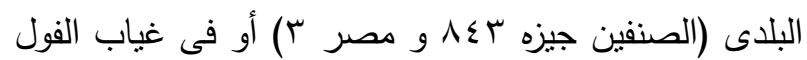
تماماً. أظهرت نتائج المعطل أن وجود جذور الحلبة مع الفول

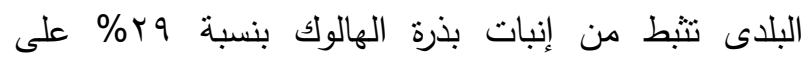
الصنف مصر ب و بنسبة rr\% على الصنف جيزة rعی بالرغم من عدم معنوية القيم مقارنة بالكنترول. أما جذور الفجل فنثطت إنبات بذره 